\title{
Cis- and trans-titanium complexes with doubly silyl-bridged dicyclopentadienyl ligands: molecular structure of $\left[(\mathrm{TiCl})_{2}(\mu-\mathrm{O})\left\{\left(\mathrm{SiMe}_{2}\right)_{2}\left(\eta^{5}-\mathrm{C}_{5} \mathrm{H}_{3}\right)_{2}\right\}\right]_{2}(\mu-\mathrm{O})_{2}$
}

\author{
A.M. Cano, J. Cano, T. Cuenca, P. Gómez-Sal ', A. Manzanero ', P. Royo * \\ Departamento de Quimica Inorgánica, Universidad de Alcalá de Henares, Campus Universitario, Edifficio Fanmacia, E-2887I Alcalá de Henares, Spain
}

Keceived 10 June 1997; received in revised form 4 Seprember 1997; accepted 20 October 1997

Dedicated to the memory of an outstanding scientist and good friend, Mark $E$. Vol'pin

\begin{abstract}
The reaction of $\mathrm{TiCl}_{4}$ with $\mathrm{Li}_{2}\left[\left(\mathrm{SiMl}_{2}\right)_{2}\left(\eta^{5}-\mathrm{C}_{5} \mathrm{H}_{3}\right)_{2} \mathrm{~J}\right.$ in roluene at room temperature afforded a mixture of cis- and trans$\left[\left(\mathrm{TiCl}_{3}\right)_{2}\left\{\left(\mathrm{SiMe}_{2}\right)_{2}\left(\eta^{5}-\mathrm{C}_{5} \mathrm{H}_{3}\right)_{2}\right)\right]$ in a molar ratio of $1 / 2$ after recrystailization. The complex trans-[( $\left.\left.\mathrm{TiCl}_{3}\right)_{2}\left\{\left(\mathrm{SiMe}_{2}\right)_{2}\left(\eta^{5}-\mathrm{C}_{5} \mathrm{H}_{3}\right)_{2}\right\}\right]$ was hydrolyzed immediately by the addition of water to THF solutions to give trans- $\left[\left(\mathrm{TiCl}_{2}\right)_{2}(\mu-\mathrm{O})\left\{\left(\mathrm{SiMe}_{2}\right)_{2}\left(\eta^{5}-\mathrm{C}_{5} \mathrm{H}_{3}\right)_{2}\right\}\right]$ as a solid insolvi:ie in all organic solvents, whereas hydrolysis of cis- $\left[\left(\mathrm{TiCl}_{3}\right)_{2}\left\{\left(\mathrm{SiMe}_{2}\right)_{2}\left(\eta^{5}-\mathrm{C}_{5} \mathrm{H}_{3}\right)_{2}\right\}\right]$ under different conditions led to the dinuclear $\mu-0 x o$ complex cis- $\left[\left(\mathrm{TiCl}_{2}\right)_{2}(\mu-\mathrm{O})\left\{\left(\mathrm{SiMe}_{2}\right)_{2}\left(\eta^{5}-\mathrm{C}_{5} \mathrm{H}_{3}\right)_{2}\right\}\right]$ and two oxo complexes of the same stoichiometry $\left[(\mathrm{TiCl})_{2}(\mu-O)_{\{}\left\{\left(\mathrm{SiMe}_{2}\right)_{2}\left(\eta^{5}-\right.\right.\right.$ $\left.\left.\left.\mathrm{C}_{5} \mathrm{H}_{3}\right)_{2}\right\}\right]_{2}\left(\mu-\mathrm{O}_{2}\right.$ as crystalline solids. Alkylation of cis- and trans- $\left[\left(\mathrm{TiCl}_{3}\right)_{2}\left(\left(\mathrm{SiMe}_{2}\right)_{2}\left(\eta^{5}-\mathrm{C}_{5} \mathrm{H}_{3}\right)_{2}\right)\right]$ with $\mathrm{MgClMe}$ led respectively to the partially alkylated $r i s-\left[\left(\mathrm{TiMe}_{2} \mathrm{Cl}\right)_{2}\left\{\left(\mathrm{SiMe}_{2}\right)_{2}\left(\eta^{5}-\mathrm{C}_{5} \mathrm{H}_{3}\right)_{2}\right\}\right]$ and the totally alkylated rans- $\left[\left(\mathrm{TiMe}_{3}\right)_{2}\left\{\left(\mathrm{SiMe}_{2}\right)_{2}\left(\eta^{5}-\mathrm{C}_{5} \mathrm{H}_{3}\right)_{2}\right\}\right]$ compousds. The crystal and molecular structure of the tetranuclear oxo complex $\left[(\mathrm{TiCl})_{2}(\mu-\mathrm{O})\left\{\left(\mathrm{SiMe}_{2}\right)_{2}\left(\eta^{\circ}-\mathrm{C}_{5} \mathrm{H}_{3}\right)_{2}\right\}\right]_{2}(\mu-\mathrm{O})_{2}$, was determined by X-ray diffraction. (c) 1998 Elsevier Science S.A. All rights reserved.
\end{abstract}

Keywords: Crystal structures; Titanium compieres: Silyl-bridged cyclopentadienyl complexes

\section{Introduction}

Extensive studies have becn carried out on complexes containing the so-called ansa-ligands, with relation to their catalytic applications [1] in Ziegler-Natta polymerization of olefins to produce highly stereoregular iso- and syndio-tactic polymers. The use of bridged silyldicyclopentadienylligands provides access to new types of mono- and bent dicyclopentadienyl-type metal complexes. Doubly silyl-bridged cyclopentadienyl compounds [2] and some of their transition metal complexes [3,4] have been reported. Related ringsubstituted group 4 metal derivatives have also been described more recently [5]. The use of these silyl-bridged ligands provides more rigid systems $[3,6]$ which avoid the participation of ring carbon-hydrogen activation reactions; in addition, the presence of electron-withdrawing silyl groups enhances the accessibility of lower oxidation states [3,7]. We have reported previously the isolation of new group 4

\footnotetext{
* Comesponding authors.

' X-ray diffraction studies.
}

metal monocyclopentadienyl- [8], ansa-dicyclopentadienyl$[8 b, 9]$ and dicyclopentadienyl-type [10] complexes coataining singly and doubly $\mathrm{SiMe}_{2}$ bridged cyclopentadienyl ligands. Dinuclear dicyclopentadienyl-type complexes [11] with the doubly bridged ligand and with only one of the rings coordinated to the metal [12] have also been reported.

In this paper we report the synthesis and structural characterization of new cis-and trans-dinuclear chloro-, oxoand methyl-titanium monocyclopentadienyl-type complexes and the $\mathrm{X}$-ray molecular structure of the oxo-derivative $\left[(\mathrm{TiCl})_{2}(\mu-\mathrm{O})\left\{\left(\mathrm{SiMe}_{2}\right)_{2}\left(\eta^{5}-\mathrm{C}_{4} \mathrm{H}_{3}\right)_{2}\right\}\right]_{2}(\mu-\mathrm{O})_{2}$.

\section{Results and discussion}

Whereas the reaction of $\mathrm{TiCl}_{4}$ with the dithallium salt of the ligand $[8 b]$ in toluene led to the selective formation of trans-[ $\left.\left(\mathrm{TiCl}_{3}\right)_{2}\left\{\left(\mathrm{SiMe}_{2}\right)_{2}\left(\eta^{5}-\mathrm{C}_{5} \mathrm{H}_{3}\right)_{2}\right\}\right]$ (1) in $30 \%$ yield, a similar reaction with the dilithium salt in toluene always afforded a mixture with a variable proportion of the cis-1 and trans-1 isomers, as shown in Scheme 1. All attempts made 
2 polymer represented in Scheme 2, formed by one $\mu$-0xo bridge between each dinuclear unit, whose molecular weight could not be determined.

When an NMR tube containing a solution of cis-1 in wet benzene- $d_{6}\left(0.01 \% \mathrm{H}_{2} \mathrm{O}\right)$ was allowed to stand for I week. yellow crystals formed, which were identified as $\left[(\mathrm{TiCl})_{2}-\right.$ $\left.(\mu-\mathrm{O})\left\{\left(\mathrm{SiMe}_{2}\right)_{2}\left(\eta^{5}-\mathrm{C}_{5} \mathrm{H}_{3}\right)_{2}\right\}\right\}_{2}(\mu-\mathrm{O})_{2}$ (3) by 'H NMR spectroscopy; the molecular structure was determined by $\mathrm{X}$-ray diffraction methods.

When a similar reaction was carried out on a preparative level by the addition of 1 equiv. of water to a toluene solution of cis-1, the dinuclear oxo-complex cis-2 was isolated on evaporation as a yellow crystalline solid soluble in hexane and toluene. Further hydrolysis was observed when toluene or acetonitrile solutions of $\mathrm{cis}-1$ were treated with 2 equiv. of water in the presence of $\mathrm{NEt}_{3}$, leading to the isolation of complex $\mathbf{4}$ as a yellow microcrystalline solid soluble in chloroform, benzene and toluene but less soluble in hexane, although crystals of good quality for X-ray diffraction could not be obtained. The ${ }^{1} \mathrm{H}$ and ${ }^{13} \mathrm{C}$ NMR spectra of complex cis-2 show two resonances for the two pairs of equivalent $\mathrm{SiMe}_{2}$ groups and the expected $\mathrm{AA}^{\prime} \mathrm{B}$ spin system for the ring protons, indicating that the bridging oxygen is in the plane of symmetry of the molecule. The. ${ }^{1} \mathrm{H}$ NMR spectra of both oxo-complexes 3 and 4 show the same pattern (see Section 4), with four resonances for the $\mathrm{SiMe}_{2}$ groups and an $\mathrm{ABC}$ spin system for the ring protons, which is not resolved in chloroform- $d_{1}$ but was observed in benzene- $d_{6}$ and confirmed by the ${ }^{13} \mathrm{C}$ NMR spectrum of 4 . This is consistent with the molecular structure determined by $\mathrm{X}$-ray diffraction for complex 3, which shows symmetric dicyclopentadienyl ligands each also containing symmetric rings with an $A B C$ spin system. The similar NMR behavior found for complex 4 suggests that this compound may be a conformational isomer of 3 with all four chlorine atoms on the same side of the $\mathrm{Ti}_{4}$ plane, and the two bridged cyclopentadienyl systems on the opposite side instead of the alternating disposition observed for complex 3 , as discussed below.

The alkylation of complexes cis-1 and trans-1 was studied using $\mathrm{MgClMe}$ as alkylating agent (Schente 3). The addition of 6 equiv. of $\mathrm{MgClMe}$ to a hexane solution of trans-1 gave a yellow solution from which the hexamethyl dititanium $\left[\left(\mathrm{TiMe}_{3}\right)_{2}\left\{\left(\mathrm{SiMe}_{2}\right)_{2}\left(\eta^{5}-\mathrm{C}_{5} \mathrm{H}_{3}\right)_{2}\right\}\right]$ trans-5 complex was isolated as a crystalline very air sensitive yellow solid, very soluble in hexane, which was characterized by elemental analysis and NMR spectroscopy. As the trans- $\mu$-oxo complex 2 could not be characterized structurally because of its poor solubility in all organic solvents, we tried to obtain the expected more soluble methylated compound by reacting complex 2 with 4 equiv. of $\mathrm{MgClMe}$. This reaction takes place readily to give a yellow-green solution, which contains three different components, one being the hexamethylated derivative 5, together with an unresolvable mixture of oxo-compounds, which show $\boldsymbol{r}(\mathbf{M}-0)$ IR absorptions at $800 \mathrm{~cm}^{-1}$ and $860 \mathrm{~cm}^{-1}$.

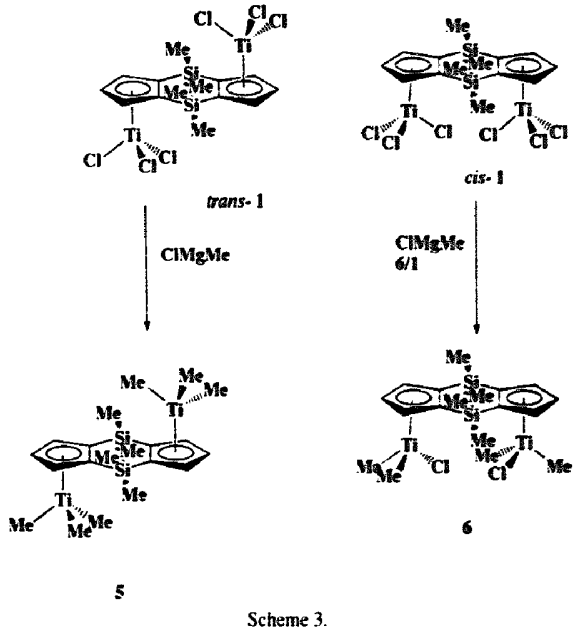

The analogous reaction carried out with cis-1 led to the tetramethyl dititanium derivative $\left[\left(\mathrm{TiMe}_{2} \mathrm{Cl}\right)_{2}\left(\left(\mathrm{SiMe}_{2}\right)_{2}-\right.\right.$ $\left.\left.\left(\eta^{5}-\mathrm{C}_{5} \mathrm{H}_{3}\right)_{2}\right\}\right]$ cis-6, even in the presence of 2 equiv. excess of the alkylating agent. Both complexes 5 and 6 are air sensitive and partial hydrolysis takes place on exposure to air. Complex 6 is soluble in hexane from which it can be recrystallized as a yellow microcrystalline solid; this was characterized by elemental analysis and NMR spectroscopy. The presence of only one signal for all the $\mathrm{SiMe}_{2}$ protons and one signal for all the Ti-Me groups confirms the expected trans disposition of the two metal fragments in complex 5 . The ${ }^{\mathrm{t}} \mathrm{H}$ NMR spectrum of complex 6 shows two resonances for the $\mathrm{SiMe}_{2}$ groups and only one resonance for all the four equivalent $\mathrm{Ti}-\mathrm{Me}$ groups, indicating the presence of a plane of symmetry and consistent with a formulation with two independent metal fragments which could also be connected by two chloro bridges, as would be expected to alleviate the electron deficiency of the metal centers.

\section{X-ray molecular structure of $\left[\mathrm{Ti}_{2}\left(\mathrm{SiMe}_{2}\right)_{2}\left(\eta^{5}-\right.\right.$ $\left.\left.\left.\mathrm{C}_{5} \mathrm{H}_{3}\right)_{2}\right\} \mathrm{Cl}_{2}(\mu-0)\right]_{2}(\mu-O)_{2}(3)$}

The molecular structure of $\mathbf{3}$ based on its X-ray structural analysis is shown in Fig. 1 with the numbering scheme employed. Selected bond angles and distances are given in Table 1.

The crystallographic molecular symmetry is $\overrightarrow{1}$, whereas the approximate symmetry is even higher $(2 / \mathrm{m})$. The molecular structure confirms that 3 can be regarded as the dimer of the dinuclear fragment $\left[(\mathrm{TiCl})_{2}\left(\mu_{2}-\mathrm{O}\right)\left\{\left(\mathrm{SiMe}_{2}\right)_{2}\left(\eta^{5}-\right.\right.\right.$ $\left.\left.\left.\mathrm{C}_{5} \mathrm{H}_{3}\right)_{2}\right\}(\mu-\mathrm{O})\right]$ affording a tetranuclear derivative showing a non-planar ' $\mathrm{Ti}_{4} \mathrm{O}_{4}$ ' core with a chair conformation in which the oxygen bridges in each dinuclear fragment are located 


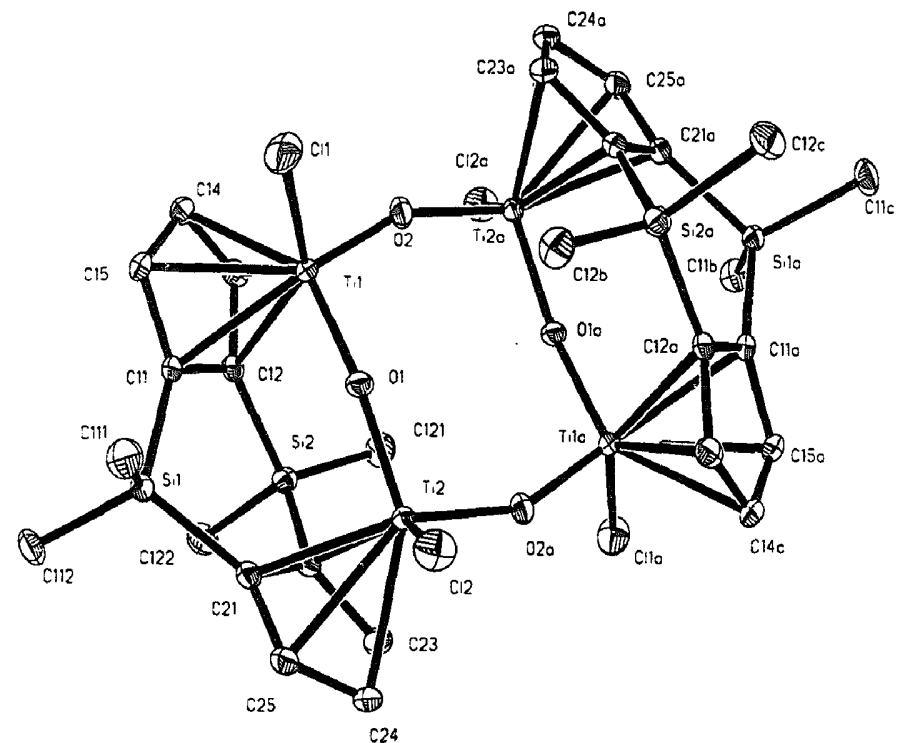

Fig. 1. ORTEP drawing of the molecular structure of compound 3 together with the atomic labeling scheme.

Table 1

Selected bond lengths $(. \dot{A})$ and angles $\left({ }^{\circ}\right)$ for complex 3

\begin{tabular}{|c|c|}
\hline $\mathrm{Ti}(1)-\mathrm{O}(2)$ & $1.798(4)$ \\
\hline $\mathrm{Ti}(1)-\mathrm{Cl}(1)$ & $2.268(2)$ \\
\hline $\mathrm{Ti}(1)-\mathrm{C}(11)$ & $2.352(5)$ \\
\hline $\mathrm{Ti}(1)-\mathrm{C}(15)$ & $2.382(5)$ \\
\hline $\operatorname{Ti}(2)-O(2 a)$ & $1.812(4)$ \\
\hline $\mathrm{Ti}(2)-\mathrm{Cl}(2)$ & $2.270(2)$ \\
\hline $\operatorname{Ti}(2)-C(21)$ & $2.354(5)$ \\
\hline $\mathrm{Ti}(2)-\mathrm{C}(24)$ & $2.388(6)$ \\
\hline $\mathrm{O}(2)-\mathrm{Ti}(2 \mathrm{a})$ & $1.812(4)$ \\
\hline $\operatorname{Si}(1)-C(112)$ & $1.867(6)$ \\
\hline$S i(1)-C(21)$ & $1.876(6)$ \\
\hline $\operatorname{Si}(2)-C(22)$ & $1.868(6)$ \\
\hline $\operatorname{Si}(2)-C(12)$ & $1.876(6)$ \\
\hline$C(11)-C(12)$ & $1.451(8)$ \\
\hline$C(13)-C(14)$ & $1.397(9)$ \\
\hline$C(21)-C(25)$ & $1.411(8)$ \\
\hline$C(22)-C(23)$ & $1.427(8)$ \\
\hline$C(24)-C(25)$ & $1.423(9)$ \\
\hline $\mathrm{Ti}(1)-\mathrm{O}(1)$ & $1.803(4)$ \\
\hline $\operatorname{Ti}(1)-C(12 ;$ & $2.329(5)$ \\
\hline $\operatorname{Ti}(1)-\mathrm{C}(13)$ & $2.370(5)$ \\
\hline $\mathrm{Ti}(1)-\mathrm{C}(14)$ & $2.394(5)$ \\
\hline $\operatorname{Ti}(2)-O(1)$ & $1.814(4)$ \\
\hline $\mathrm{Ti}(2)-\mathrm{C}(22)$ & $2.326(6)$ \\
\hline $\operatorname{Ti}(2)-\mathrm{C}(23)$ & $2.360(6)$ \\
\hline $\mathrm{Ti}(2)-\mathrm{C}(25)$ & $2.395(6)$ \\
\hline$S i(1)-C(111)$ & $1.848(7)$ \\
\hline $\mathrm{Si}(1)-C(11)$ & $1.874(5)$ \\
\hline $\operatorname{Si}(2)-C(121)$ & $1.850(7)$ \\
\hline $\operatorname{Si}(2)-C(122)$ & $1.870(6)$ \\
\hline
\end{tabular}

Table 1 (continued)

\begin{tabular}{|c|c|}
\hline$C(11)-C(15)$ & $1.416(7)$ \\
\hline$C(12)-C(13)$ & $1.409(8)$ \\
\hline$C(14)-C(15)$ & $1.409(8)$ \\
\hline$C(21)-C(22)$ & $1.441(8)$ \\
\hline $\mathrm{C}(23)-\mathrm{C}(24)$ & $1.384(9)$ \\
\hline$O(2)-T i(1)-O(1)$ & $104.5(2)$ \\
\hline $\mathrm{O}(1)-\mathrm{Ti}(1)-\mathrm{Cl}(1)$ & $102.61(14)$ \\
\hline $\mathrm{O}(2 \mathrm{a})-\mathrm{Ti}(2)-\mathrm{Cl}(2)$ & $101.40(14)$ \\
\hline $\operatorname{Ti}(1)-O(1)-T i(2)$ & $160.7(2)$ \\
\hline$C(111)-S i(1)-C(112)$ & $110.7(3)$ \\
\hline$C(112)-S i(1)-C(11)$ & $108.6(3)$ \\
\hline$C(112)-S i(1)-C(21)$ & $110.5(3)$ \\
\hline$C(121)-S i(2)-C(22)$ & $113.9(3)$ \\
\hline $\mathrm{C}(22)-\mathrm{Si}(2)-\mathrm{C}(122)$ & $106.8(3)$ \\
\hline$C(22)-S i(2)-C(12)$ & $104.0(3)$ \\
\hline $\mathrm{O}(2)-\mathrm{Ti}(1)-\mathrm{Cl}(1)$ & $101.5(2)$ \\
\hline$O(2 a)-T i(2)-O(1)$ & $103.3(2)$ \\
\hline $\mathrm{O}(1)-\mathrm{Ti}(2)-\mathrm{Cl}(2)$ & $104.34(14)$ \\
\hline $\mathrm{Ti}(1)-\mathrm{O}(2)-\mathrm{Ti}(2 \mathrm{a})$ & $153.0(2)$ \\
\hline$C(111)-S i(1)-C(11)$ & $111.8(3)$ \\
\hline$C(111)-S i(1)-C(21)$ & $110.6(3)$ \\
\hline$C(11)-S i(1)-C(21)$ & $104.5(2)$ \\
\hline$C(121)-S i(2)-C(122)$ & $111.4(3)$ \\
\hline$C(121)-S i(2)-C(12)$ & $111.8(3)$ \\
\hline$C(122)-S i(2)-C(12)$ & $108.5(3)$ \\
\hline
\end{tabular}

above and below the plane formed by the four $\mathrm{Ti}$ atoms, whereas the oxygen bridges between the titanium atoms of different fragments are very close to the plane. The two chloro atoms and the dicyclopentadienyl system of each fragment 
occupy alternate sides with respect to the ' $\mathrm{Ti}_{4} \mathrm{O}_{4}$ ' core. This disposition is similar to the chair conformation found for $\left[\mathrm{Ti}_{2}\left\{\left(\mathrm{SiMe}_{2}\right)\left(\eta^{5}-\mathrm{C}_{5} \mathrm{H}_{4}\right)_{2}\right\} \mathrm{Cl}_{2}(\mu-\mathrm{O})\right\}_{2}(\mu-\mathrm{O})_{2}$ [ [8a], containing a singly bridged dicyclopentadienyl system, and the planar conformation found for $\left[\mathrm{Ti}\left(\eta^{5}-\mathrm{C}_{5} \mathrm{HMe}_{4}\right)_{2}\right\} \mathrm{Br}(\mu$ O) $]_{4}[13]$ and $\left[\left\{\mathrm{Ti}\left(\eta^{5}-\mathrm{C}_{5} \mathrm{H}_{4} \mathrm{SiMe}_{3}\right)(\mathrm{NCS})(\mu-\mathrm{O})\right\}_{4}\right][14]$ with non-bridged cyclopentadienyl rings. All the titaniumoxygen distances in the ' $\mathrm{Ti}_{4} \mathrm{O}_{4}$ ' core are similar (between 1.798(4) and 1.814(4) $\AA$ ) and the $\mathrm{Ti}(1) \mathrm{O}(1) \mathrm{Ti}(2)$ and $\mathrm{Ti}(1) \mathrm{O}(2) \mathrm{Ti}(2 \mathrm{a})$ angles are very close, their values being $160.7(2)^{\circ}$ and $153.0(2)^{\circ}$ respectively. Each titanium is coordinated tetrahedrally to two oxygen atoms, one chlorine atom and one cyclopentadienyl ring, with angles between $101.5^{\circ}$ and $115.9^{\circ}$. The two silicon bridging atoms and the carbon atoms of their methyl groups are located in the same plane with the two cyclopentadienyl rings in a necessarily eclipsed configuration. The dihedral angle between the ring planes of each bridging cyclopentadienyl ligand is closer $\left(32.5(2)^{\circ}\right.$, than that found $\left(64.35(6)^{\circ}\right)$ for $\left[\mathrm{Ti}\left\{\left(\mathrm{SiMe}_{2}\right)_{2}\left(\eta^{5}-\right.\right.\right.$ $\left.\left.\mathrm{C}_{5} \mathrm{H}_{3}\right)_{2}\right\} \mathrm{Cl}_{2}$ ] [8b], owing to the presence of one oxygen bridge between both bridged titanium atoms with a $\mathrm{Ti}(1) \mathrm{O}(:) \mathrm{Ti}(2)$ angle of $160.7(2)^{\circ}$, and the two silicon atoms $\mathrm{ce}$ coplanar with the cyclopentadienyl carbon atoms of each of these rings. The mean $\mathrm{Ti}-\mathrm{Cl}$ distance 2.269(2) $\AA$ is between those found for the related monocyclopentadienyland metallocene-type chloride complexes.

\section{Experimental}

All manipulations were performed under an inert atmosphere of argon or nitrogen using syringes or cannulae through Subaseals in Schlenk tubes using high vacuum line techriques or a VAC model HE 63P glovebox. Solvents were dried and distilled under nitrogen, $\mathrm{CH}_{2} \mathrm{Cl}_{2}$ over $\mathrm{P}_{4} \mathrm{O}_{10}$, diethyl ether and tetrahydrofuran from sodium benzophenone ketyl, benzene and toluene from sodium, and hexane from sodiumpotassium alloy. 4,4,8,8-Tetramethyltetrahydro-4,8-disila-sindacene and $\mathrm{Li}_{2}\left[\left(\mathrm{SiMe}_{2}\right)_{2}\left(\eta^{3}-\mathrm{C}_{5} \mathrm{H}_{3}\right)_{2}\right]$ were prepared according to literature procedures [2]. $\mathrm{MeLi}$ ( $1.6 \mathrm{M}$ solution in diethyl ether), $\mathrm{MeMgCl}$, and $\mathrm{TiCl}_{4}$ (Aldrich) were obtained commercially and used as received. The ${ }^{1} \mathrm{H}$ and ${ }^{1.3} \mathrm{C}$ NMR spectra were recorded at 299.95 and $75.43 \mathrm{MHz}$ respectively on a Varian Unity 300 spectrometer; chemical shifts, in ppm, are positive downfield with respect to externai $\mathrm{SiMe}_{4}$; coupling constants are in $\mathbf{H z}$. IR spectra were recorded in Nujol mulls for solids on a Perkin-Elmer 583 spectrophotometer. $\mathrm{C}$ and $\mathrm{H}$ analyses were performed with a Perkin-Elmer 240-B microanalyzer. Mass spectra were recorded in a Hewlett-Packari $5988 \mathrm{~A}$ spectrometer.

\subsection{Reaction of $\mathrm{TiCl}_{4}$ with $\mathrm{Li}_{2}\left(\left(\mathrm{SiMe}_{2}\right)_{2}\left(\eta^{\overline{3}}-\mathrm{C}_{3} \mathrm{H}_{3}\right)_{2} \mathrm{I}\right.$}

A suspension of $2.41 \mathrm{~g}(9.42 \mathrm{mmol})$ of $\mathrm{Li}_{2}\left[\left(\mathrm{SiMe}_{2}\right)_{2}\left(\eta^{5}-\right.\right.$ $\left.\left.\mathrm{C}_{5} \mathrm{H}_{3}\right)_{2}\right]$ in $75 \mathrm{mi}$ of toluene was treated with a solution of $2.17 \mathrm{ml}(19.77 \mathrm{mmol})$ of $\mathrm{TiCl}_{4}$ in $25 \mathrm{ml}$ of toluene. After being stirred for $5 \mathrm{~h}$ at room temperature the $\mathrm{LiCl}$ formed was removed by filtration and the red solution was concentrated, under vacuum, to a final volume of $20 \mathrm{ml}$. The solution was then cooled at $-35^{\circ} \mathrm{C}$ for $12 \mathrm{~h}$ to give a yellow crystalline solid which after being filtered, washed with hexane and dried under vacuum, was characierized as trans- $\left[\left(\mathrm{TiCl}_{3}\right)_{2}-\right.$ $\left.\left\{\left(\mathrm{SiMe}_{2}\right)_{2}\left(\eta^{5}-\mathrm{C}_{5} \mathrm{H}_{3}\right)_{2}\right\}\right]$ (1) $(2.07 \mathrm{~g}, 3.75 \mathrm{mmol}, 40 \%$ yield). The residual solution was evaporated to dryness to give a solid which was then recrystallized repeatedly from toluene to give yellow crystals of cis- $\left[\left(\mathrm{TiCl}_{3}\right)_{2}\left\{\left(\mathrm{SiMe}_{2}\right)_{2}\right.\right.$ ( $\left.\left.\left.\eta^{5}-\mathrm{C}_{5} \mathrm{H}_{3}\right)_{2}\right\}\right]$ (1) (1.55 g. $2.81 \mathrm{mmol}$, 30\% yield). When the same reaction was carried out heating the mixture at $60^{\circ} \mathrm{C}$. the molar ratio of cis/trans isomers was $1 / 1$ but the total yield was decreased owing to the presence of unrecovered decomposition products. Data for cis-1. Anal. Calc. for $\mathrm{C}_{14} \mathrm{H}_{1 \mathrm{~S}} \mathrm{Si}_{2}-$ $\mathrm{Ti}_{2} \mathrm{Cl}_{6} ; \mathrm{C}, 30.52 ; \mathrm{H}, 3.29$. Found: C, 31.03; H. 3.61\%. 'H NMR ( $\left.300 \mathrm{MHz}_{2} \mathrm{CDCl}_{3}, 25^{\circ} \mathrm{C}\right): \delta 0.45(\mathrm{~s}, 6 \mathrm{H}, M e-\mathrm{Si}), 0.70$ (s, 6H, Me-Si), 6.93 (t, J=2.9 Hz, 2H, $\left.\mathrm{C}_{5} \mathrm{H}_{3} \beta\right), 7.55$ (d, $\left.J=2.9 \mathrm{~Hz}, 4 \mathrm{H}, \mathrm{C}_{5} \mathrm{H}_{3} \alpha\right) .{ }^{13} \mathrm{C}\left\{{ }^{1} \mathrm{H}\right\} \mathrm{NMR}\left(\mathrm{CDCl}_{3}\right):-4.2$ $(\mathrm{Si}-\mathrm{Me}), 1.4(\mathrm{Si}-\mathrm{Me}), 124.5\left(\mathrm{C}_{5} \mathrm{H}_{3} \beta\right), 132.7\left(\mathrm{C}_{5} \mathrm{H}_{3} \alpha\right)$, $136.8\left(\mathrm{C}_{5} \mathrm{H}_{3}\right.$ ipso). Data for trans-1. 'H NMR ( $300 \mathrm{MHz}$, $\left.\mathrm{CDCl}_{3}, 25^{\circ} \mathrm{C}\right): \delta 0.65(\mathrm{~s}, 12 \mathrm{H}, \mathrm{Me}-\mathrm{Si}), 7.13(\mathrm{t}, J=2.9 \mathrm{~Hz}$, $2 \mathrm{H}, \mathrm{C}_{9} \mathrm{H}_{3} \beta$ ), 7.57 (d. $J=2.9 \mathrm{~Hz}, 4 \mathrm{H} . \mathrm{C}_{5} \mathrm{H}_{3} \alpha$ ). ${ }^{13} \mathrm{C}\left\{{ }^{1} \mathrm{H}\right\}$ NMR $\left(\mathrm{CDCl}_{3}\right): 1.4(\mathrm{Si}-\mathrm{Me}), 129.7\left(\mathrm{C}_{9} \mathrm{H}_{3} \mathrm{\beta}\right), 132.7\left(\mathrm{C}_{5} \mathrm{H}_{3}\right.$ $\alpha), 1+1.9\left(\mathrm{C}_{5} \mathrm{H}_{3}\right.$ ipso $)$. The following labels are used in the text.

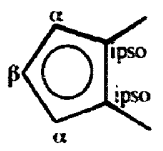

\subsection{Preparation of $\left[\left(\mathrm{TiCl}_{2}\right)_{2}(\mu-\mathrm{O})\left\{\left(\mathrm{SiMe}_{2}\right)_{2}\left(\pi^{5}-\mathrm{C}_{5} \mathrm{H}_{3}\right)_{2}\right\}\right]$ trans-2}

Deoxygenated and distilled water ( $21 \mu \mathrm{l}, 1.20 \mathrm{mmol})$ and $\mathrm{NEt}_{3}(0.33 \mathrm{ml}, 2.40 \mathrm{mmol})$ were added by syringe to a stirred solution of $0.66 \mathrm{~g}(1.20 \mathrm{mmol})$ of $\operatorname{trans}-1$ in THF and a yellow precipitate was formed immediately. The reaction mixture was maintained at room temperature for $8 \mathrm{~h}$ and then the solvent was removed under vacuum. The ammonium salt contained in the residual solid was removed by extraction into $\mathrm{CH}_{2} \mathrm{Cl}_{2}(3 \times 20 \mathrm{ml})$ to leave a yellow solid, insoluble in all organic solvents, which was characterized as trans$\left[\left(\mathrm{TiCl}_{2}\right)_{2}(\mu-\mathrm{O})\left\{\left(\mathrm{SiMe}_{2}\right)_{2}\left(\eta^{5}-\mathrm{C}_{5} \mathrm{H}_{3}\right)_{2}\right\}\right](2)(0.60 \mathrm{~g}, 1.08$ mmol, $90 \%$ yield). Data for 2. Anal. Calc. for $\mathrm{C}_{14} \mathrm{H}_{18-}$ $\mathrm{Si}_{2} \mathrm{Ti}_{2} \mathrm{Cl}_{6}: \mathrm{C}, 33.90 ; \mathrm{H}, 3.66$. Found: C, 34.05; H, 3.87\%.

\subsection{Preparation of $\left[\left(\mathrm{TiCl}_{2}\right)_{2}(\mu-\mathrm{O})\left\{\left(\mathrm{SiMe}_{2}\right)_{2}\left(\eta^{5}-\mathrm{C}_{5} \mathrm{H}_{3}\right)_{2}\right\}\right]$ cis -2}

Deoxygenated and distilled water $(19.6 \mu l, 1.09 \mathrm{mmol})$ was added by syringe to a stirred solution of $0.60 \mathrm{~g}(1.09$ 
mmol) of cis-1 in toluene. The dark red reaction mixture was maintained at room temperature for $12 \mathrm{~h}$ giving a green solution; the solvent was then removed under vacuum. The cis-2 compound was obtained by extraction into hexane $(2 \times$ $30 \mathrm{ml}$ ) from the green oil formed. Solvent was removed from the yellow solution under vacuum and a yellow microcrystalline solid was characterized as cis- $\left[\left(\mathrm{TiCl}_{2}\right)_{2}(\mu\right.$ O) $\left.\left\{\left(\mathrm{SiMe}_{2}\right)_{2}\left(\eta^{5}-\mathrm{C}_{5} \mathrm{H}_{3}\right)_{2}\right\}\right]$ (2) $(0.46 \mathrm{~g}, 0.83 \mathrm{mmol}, 85 \%$ yield).

Data for cis-2. Anal. Calc. for $\mathrm{C}_{14} \mathrm{H}_{18} \mathrm{Si}_{2} \mathrm{Ti}_{2} \mathrm{Cl}_{6}: \mathrm{C}, 33.90$; H. 3.66. Found: C, 34.53; H, 3.92\%. 'H NMR ( $300 \mathrm{MHz}$, $\left.\mathrm{CDCl}_{3}, 25^{\circ} \mathrm{C}\right): \delta 0.30(\mathrm{~s}, 6 \mathrm{H}, \mathrm{Me}-\mathrm{Si}), 0.59(\mathrm{~s}, 6 \mathrm{H}, \mathrm{Me}-\mathrm{Si})$, 7.17 (t, $\left.J=2.9 \mathrm{~Hz}, 2 \mathrm{H}, \mathrm{C}_{5} \mathrm{H}_{3}\right), 7.36$ (d, $J=2.9 \mathrm{~Hz}, 4 \mathrm{H}$, $\left.\mathrm{C}_{5} \mathrm{H}_{3}\right)$. ${ }^{13} \mathrm{C}\left\{{ }^{\prime} \mathrm{H}\right\} \mathrm{NMR}\left(\mathrm{CDCl}_{3}\right): 0.9(\mathrm{Si}-\mathrm{Me}), 2.5(\mathrm{Si}-\mathrm{Me})$, $123.7\left(\mathrm{C}_{5} \mathrm{H}_{3} \beta\right), 129.1\left(\mathrm{C}_{5} \mathrm{H}_{3} \alpha\right), 133.7\left(\mathrm{C}_{5} \mathrm{H}_{3}\right.$ ipso $)$.

\subsection{Preparation of $\left[(\mathrm{TiCl})_{2}(\mu-\mathrm{O})\left\{\left(\mathrm{SiMe}_{2}\right)_{2}\left(\eta^{5}-\mathrm{C}_{5} \mathrm{H}_{3}\right)_{2}\right\}\right]_{2-}$} $(\mu-0)_{2}(3),(4)$

\subsubsection{Method A}

A solution of $\left[\left(\mathrm{TiCl}_{3}\right)_{2}\left\{\left(\mathrm{SiMe}_{2}\right)_{2}\left(\eta^{5}-\mathrm{C}_{5} \mathrm{H}_{3}\right)_{2}\right\}\right]$ cis-1 in wet benzene- $d_{6}\left(0.01 \% \mathrm{H}_{2} \mathrm{O}\right)$ was maintained in an NMR tube for 6 days to give yellow crystals which after being filtered, washed with hexane and dried under vacuum, were characterized as complex 3. Data for 3. 'H NMR ( $300 \mathrm{MHz}$. $\mathrm{CDCl}_{3}, 25^{\circ} \mathrm{C}$ ): $\delta 0.31$ (s, 6H, Me-Si), $0.39(\mathrm{~s}, 6 \mathrm{H}, M e-\mathrm{Si}$ ), $0.62(\mathrm{~s}, 6 \mathrm{H}, M e-\mathrm{Si}), 1.01(\mathrm{~s}, 6 \mathrm{H}, M e-\mathrm{Si}), 6.67$ (m, 4H,
$\left.\mathrm{C}_{5} \mathrm{H}_{3} \beta\right), 7.06\left(\mathrm{~m}, 4 \mathrm{H}, \mathrm{C}_{5} \mathrm{H}_{3} \alpha, \alpha^{\prime}\right), 7.27\left(\mathrm{~m}, 4 \mathrm{H}, \mathrm{C}_{5} \mathrm{H}_{3} \alpha\right.$, $\left.\alpha^{\prime}\right)$.

\subsubsection{Method B}

Deoxygenated and distilled water $(33.7 \mu \mathrm{l}, 1.87 \mathrm{mmol})$ and $\mathrm{NEt}_{3}(0.51 \mathrm{ml}, 3.74 \mathrm{mmol})$ were added by syringe to a stirring solution of $0.51 \mathrm{~g}(0.94 \mathrm{mmol})$ of cis-1 in toluene. The reaction mixture was maintained at room temperature for $12 \mathrm{~h}$ and the solvent was then removed under vacium. Extraction of the residual solid into hexane $(2 \times 30 \mathrm{ml})$ gave a solution which provided yellow crystals after removal of solvent under vacuum. They were characterized as complex $4(0.4 \mathrm{~g}, 0.70 \mathrm{mmol}, 74 \%$ yield $)$.

Data for 4. Anal. Calc. for $\mathrm{C}_{28} \mathrm{H}_{36} \mathrm{Si}_{4} \mathrm{Ti}_{4} \mathrm{Cl}_{4} \mathrm{O}_{4}: \mathrm{C}, 38.12$; H, 4.11. Found: C, 38.09; H, 4.55\%. 'H NMR (300 MHz, $\mathrm{CDCl}_{3}, 25^{\circ} \mathrm{C}$ ): $\delta 0.37$ (s. $6 \mathrm{H}, \mathrm{Me}-\mathrm{Si}$ ), 0.47 (s, 6H. Me-Si), 0.53 (s, 6H, Me-Si), 0.67 (s, 6H, Me-Si), $6.87(\mathrm{~m}, 4 \mathrm{H}$, $\left.\mathrm{C}_{5} \mathrm{H}_{3} \beta\right), 7.38\left(\mathrm{~m}, 8 \mathrm{H}, \mathrm{C}_{5} \mathrm{H}_{3} \alpha, \alpha^{\prime}\right)$. 'H NMR (300 MHz, $\left.\mathrm{C}_{6} \mathrm{D}_{6}, 25^{\circ} \mathrm{C}\right): \delta 0.18(\mathrm{~s}, 6 \mathrm{H}, M e-\mathrm{Si}), 0.36(\mathrm{~s}, 6 \mathrm{H}, M e-\mathrm{Si})$, $0.38(\mathrm{~s}, 6 \mathrm{H}, M e-\mathrm{Si}), 0.64(\mathrm{~s}, 6 \mathrm{H}, \mathrm{Me}-\mathrm{Si}), 6.33$ (m, 4H, $\left.\mathrm{C}_{5} \mathrm{H}_{3} \beta\right), 6.99\left(\mathrm{~m}, 4 \mathrm{H}, \mathrm{C}_{5} \mathrm{H}_{3} \alpha, \alpha^{\prime}\right), 7.02\left(\mathrm{~m}, 4 \mathrm{H}, \mathrm{C}_{5} \mathrm{H}_{3} \alpha\right.$, $\left.\alpha^{\prime}\right),{ }^{13} \mathrm{C}\left\{{ }^{\prime} \mathrm{H}\right\}$ NMR $\left(\mathrm{CDCl}_{3}\right):-0.5(\mathrm{Si}-\mathrm{Me}), 0.9(\mathrm{Si}-\mathrm{Me})$, $1.7(\mathrm{Si}-\mathrm{Me}), 3.0(\mathrm{Si}-\mathrm{Me}), 123.7\left(\mathrm{C}_{5} \mathrm{H}_{3} \beta\right), 135.5,136.1$ $\left(\mathrm{C}_{5} \mathrm{H}_{3} \alpha, \alpha^{\prime}\right), 135.1,136.8\left(\mathrm{C}_{5} \mathrm{H}_{3}\right.$ ipso $)$.

\subsection{Synthesis of trans-[(TiMe $\left.)_{3}\right)_{2}\left\{\left(\mathrm{SiMe}_{2}\right)_{2}\left(\eta^{5}-\mathrm{C}_{5} \mathrm{H}_{3}\right)_{2}\right\} /(5)$}

$\mathrm{MgClMe}$ ( $3.63 \mathrm{ml}$ of a $3 \mathrm{M}$ THF solution, $10.89 \mathrm{mmol}$ ) was added at $-78^{\circ} \mathrm{C}$ to a suspension of trans $-1(1.05 \mathrm{~g}, 1.81$

Table 2

Crystal data and structure refinement for complex 3

\begin{tabular}{|c|c|}
\hline Empirical formula & $\mathrm{C}_{2 \mathrm{x}} \mathrm{H}_{36} \mathrm{Ti}_{4} \mathrm{O}_{4} \mathrm{Cl}_{4} \cdot \mathrm{l} / 2 \mathrm{C}_{\mathrm{h}} \mathrm{H}_{\mathrm{t}}$ \\
\hline Formula weight & 469.69 \\
\hline Temperature ( $\mathbf{K})$ & $293(2)$ \\
\hline Wavelength (A) & 0.71073 \\
\hline Crystal system & monoclinic \\
\hline Space group & $P q_{-1} / n$ \\
\hline \multicolumn{2}{|l|}{ Unit cell dimensions } \\
\hline$a(\dot{A})$ & $9.709(4)$ \\
\hline$b(A)$ & $15.112(3)$ \\
\hline$c(\dot{A})$ & $14.700(5)$ \\
\hline$\beta\left(^{\circ}\right)$ & $100.60(2)$ \\
\hline Volume $\left(\AA^{3}\right)$ & $2120 .(1)$ \\
\hline$Z$ & 2 \\
\hline Density (calc.) $\left(\mathrm{g} \mathrm{cm}^{3}\right)$ & 1.443 \\
\hline Absorption coefificient $\left(\mathrm{cm}^{-1}\right)$ & 11.23 \\
\hline$F(000)$ & 938 \\
\hline Crystal size $(\mathrm{mm})$ & $0.2 \times 0.2 \times 0.3$ \\
\hline$\theta$ Range for data collection $\left(^{\circ}\right)$ & 2 to 25 \\
\hline Index ranges & $-11<h<11,0<k<17,0<1<17$ \\
\hline Reflections collected & 3878 \\
\hline Independent reflections & $3727\left(R_{\mathrm{wn1}}=0.0421\right)$ \\
\hline Refinement method & full-matrix least-squares on $F^{2}$ \\
\hline Data, restraints. parameters & $3727,0.226$ \\
\hline Goodness-of-fit on $F^{2}$ & 1.053 \\
\hline Final $R$ indices $(I>2 \sigma(l))^{4}$ & $R 1=0.0487 . \omega R 2=0.1598$ \\
\hline $\mathbf{R}$ indices (all data) & $R I=0.0848, \omega R 2=0.1691$ \\
\hline Weighting scheme & calc. $\omega=1 /\left[\sigma^{2}\left(F_{n}{ }^{2}\right)+(0.0944 P)^{2}+3.0549 P !\right.$ where $P=\left(F_{0}{ }^{2}+2 F_{v}{ }^{2}\right) / 3$ \\
\hline Lurgest difference pak, hole (e A ') & $1.004,-0.316$ \\
\hline
\end{tabular}

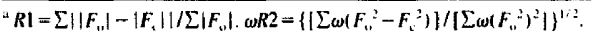


$\mathrm{mmol})$ in hexane $(50 \mathrm{ml})$. The reaction mixture was warmed to room temperature and stirred for $12 \mathrm{~h}$. After filtration the scivent was removed under vacuum and the resulting solid was recrystallized from hexane to give $5(0.56 \mathrm{~g}, 1.30 \mathrm{mmol}$, $73 \%$ yield).

Data for 5. Anal. Calc. for $\mathrm{C}_{20} \mathrm{H}_{30} \mathrm{Si}_{2} \mathrm{Ti}_{2}: \mathrm{C}, 56.07 ; \mathrm{H}, 8.47$. Found: C, 55.75; H, 8.53\%. ' $\mathrm{H}$ NMR ( $300 \mathrm{MHz} . \mathrm{CDCl}_{3}$, $\left.25^{\circ} \mathrm{C}\right): \delta 0.21$ (s, 12H, Me-Si), $1.29(\mathrm{~s}, 18 \mathrm{H}, M e-\mathrm{Ti}), 6.17$ $\left(\mathrm{t}, J=2.9 \mathrm{~Hz}, 2 \mathrm{H}, \mathrm{C}_{5} \mathrm{H}_{3} \beta\right.$ ), 6.35 (d, $J=2.9 \mathrm{~Hz}, 4 \mathrm{H}, \mathrm{C}_{5} \mathrm{H}_{3}$ $\left.\alpha, \alpha^{\prime}\right) .{ }^{13} \mathrm{C}\left\{{ }^{\prime} \mathrm{H}\right\}$ NMR $\left(\mathrm{CDCl}_{3}\right): 1.6(\mathrm{Si}-\mathrm{Me}), 64.4(\mathrm{Ti}-$ $M e), 120.7\left(\mathrm{C}_{5} \mathrm{H}_{3} \beta\right), 124.3\left(\mathrm{C}_{5} \mathrm{H}_{3} \alpha\right), 129.8\left(\mathrm{C}_{5} \mathrm{H}_{3}\right.$ ipso $)$.

\subsection{Synthesis of cis-if(TiMe $\left.\left.{ }_{2} \mathrm{Cl}\right)_{2}\left\{\left(\mathrm{SiMe}_{2}\right)_{2}\left(\eta^{5}-\mathrm{C}_{5} \mathrm{H}_{4}\right)_{2}\right\}\right](6)$}

MgClMe ( $3.84 \mathrm{ml}$ of a $3 \mathrm{M}$ THF solution, $11.58 \mathrm{mmol}$ ) was added at $-78^{\circ} \mathrm{C}$ to a suspension of $c i s-1(1.05 \mathrm{~g}, 1.92$ $\mathrm{mmol})$ in hexane $(50 \mathrm{ml})$. The reaction mixture was warmed to room temperature and stirred for $12 \mathrm{~h}$. After filtration the solvent was removed under vacuum and the resulting solid was recrystallized from hexane to give $6(0.48 \mathrm{~g}, 1.02 \mathrm{mmol}$, $58 \%$ yield).

Data for 6. Anal. Calc. for $\mathrm{C}_{14} \mathrm{H}_{18} \mathrm{Si}_{2} \mathrm{Ti}_{2} \mathrm{Cl}_{4} \mathrm{O}: \mathrm{C}, 46.07 ; \mathrm{H}$, 6.44. Found: C, $46.45 ; \mathrm{H}, 6.31 \%$. 'H NMR ( $300 \mathrm{MHz}$. $\left.\mathrm{CDCl}_{3}, 25^{\circ} \mathrm{C}\right): \delta 0.04(\mathrm{~s}, 6 \mathrm{H}, \mathrm{Me}-\mathrm{Si}), 0.17(\mathrm{~s}, 6 \mathrm{H}, \mathrm{Me}-\mathrm{Si})$, $0.92(\mathrm{~s}, 12 \mathrm{H}, \mathrm{Me}-\mathrm{Ti}), 6.63\left(\mathrm{t}, J=2.9 \mathrm{~Hz}, 2 \mathrm{H}, \mathrm{C}_{5} \mathrm{H}_{3} \beta\right), 6.71$ (d, $\left.J=2.9 \mathrm{~Hz}, 4 \mathrm{H}, \mathrm{C}_{5} \mathrm{H}_{3} \alpha\right) .{ }^{13} \mathrm{C}\left\{{ }^{\prime} \mathrm{H}\right\}$ NMR $\left(\mathrm{CDCl}_{3}\right):-3.4$ $(\mathrm{Si}-\mathrm{Me}), 2.9(\mathrm{Si}-\mathrm{Me}), 53.2(\mathrm{Ti}-\mathrm{Me}), 121.8\left(\mathrm{C}_{5} \mathrm{H}_{3} \beta\right)$, $124.0\left(\mathrm{C}_{5} \mathrm{H}_{3} \alpha\right), 126.8\left(\mathrm{C}_{5} \mathrm{H}_{3}\right.$ ipso $)$.

\subsection{X-ray structural determination for compound 3}

Crystallographic and experimental details of the crystal structure determination are given in Table 2. Suitable crystals of complex 3 were mounted on an Enraf-Nonius Cad4 automatic four-circle diffractometer with bisecting geometry, equipped with a graphite-oriented monochromator and Mo $\mathrm{K} \alpha$ radiation $(\lambda=0.71073 \AA$ ). Data were collected at room temperature. Intensities were corrected for Lorentz and polarization effects in the usual manner. No absorption or extinction corrections were made.

The structures were solved by direct methods (SHELXS 90) [15] and refined by full-matrix least-squares against $F^{2}$ (SHELXL 93) [16]. All non-hydrogen atoms were refined anisotropically. In the last cycle of refinement the hydrogen atoms were positioned geometrically and refined using a riding model with thermal parameters equivalent to that of the carbon atom to which they were attached. Calculations were carried on an ALPHA AXP (Digital) workstation.

\section{Supplementary material}

Tables of atomic coordinates and isotropic displacement parameters. full lists of bond distances and angles, anisotropic displacement parameters, hydrogen coordinates and structure factors have been deposited with the Cambridge Crystallographic Data Centre, 12 Union Road, Cambridge CB2 1EZ. UK.

\section{Acknowledgements}

This research is included in the EEC COST-D2/03/92 Project. We gratefully acknowledge financial support by DGICYT (Project 92-0178-C). J.C. acknowledges Universidad de Alcalá for a fellowship.

\section{References}

[1] H.H. Brintzinger, D. Fischer, R. Mulhaupt, B. Rieger, R.M. Waymouth, Angew. Chem. Int. Ed. Engl, 34 (1995, 11+3.

[2] (a) J. Hiermeier, F.H. Köhler, G. Müller, Organometallics 10 ( 1991 ) 1787: (b) P. Jutzi. Chem. Rev. 86 ( 1986) 983.

[3] H. Atzkem, B. Huber. F.H. Köhler. G. Müller. R. Mïller, Organometallics 10 ( 1991$) 238$.

[4] (a) U. Siemeling. P. Jutzi, B. Neumarn. H.-G. Stamaler. M.B. Hursthouse, Organometallics 11 ( 1992) 1328; (b) I. Mieling, Ph.D. Dissertation, University of Bielefeld, Germany, 1993.

[5] (a) W. Mengele, J. Diebold. C. Troll, W. Röll, H.H. Bristzinger. Organometallics 12 ( 1993) 1931: (b) T.A. Herzog, D.L. Zubris, J.E. Bercaw, J. Am. Chem. Soc. 118 ( 1996$) 11988$.

[6] T. Cuenca, M. Galakhov, E. Royo, P. Royo.J. Organomet. Chem 515 (1996) 33.

[7] (a) R. Gómez. T. Cuenca, P. Royo, M.A. Pellinghelli, A. Tiripicchio, Organometallics 10 (1991) 1505: (b) T. Cuencar R. Gómez. P. Gómez-Sal, P. Royo, J. Organomet. Chem. 454 ( 1993 ) 105; (c) T. Cuenca, A. Padilla, P. Royo, M. Parra-Hake, M.A. Pellinghelli. A. Tiripicchio, Organometallics 14 ( 1995) 848.

[8] (a) S. Cinulos, T. Cuenca. I.C. Flores, R. Gönez, P. Gömez-Sal. P. Royo, Otganometallics 12 ( 1993 ) 944: (b) A. Cano. T. Cuenaca P. Gómez-Sal, B. Royo, P. Royo, Organometallics 13 (1994) 1688.

[9] (a) R. Gómez, T. Cuenca, P. Royo, J. Organomet. Chem. 382 ( 1990) 103: (b) R. Gómez, T. Cuenca, P. Royo, E. Hovestreydt, Organometalics 10 (1991) 2516; (c) A. Cano, T. Cuenca, P. Gómez-Sal, A. Manzanero, P. Royo, J. Organomet. Chen. 526 ( 1996) 227.

[10] (a) T. Cuenca, J.C. Flores, R. Gómez, P. Gómez-Sal M. Parra-Hake, P. Royo, Inorg. Chem. 32 ( 1993) 3608; (b) G. Cinelo, T. Cuenca, P. Gómez-Sal, A. Marin, P. Royo, J. Chem. Soc., Dahon Trans. (1995) 23i.

[1I] J.C. Corey, J.L. Huhmann. N.P. Rath. inorg. Chem. 34 ( 1995 ) 3203.

[12] (a) H. Lang, S. Blau, A. Muth, K. Weiss, U. Neugebauer, J. Crganomet. Chen. 490 ( 1995 ) C32.

[13] S.I. Troyanov, V. Varga. K. Mach, J. Organomet. Chem. 402 (1991) 201.19

[14] T. Carotiglio, C. Floriani. A. Sgamelloti, A. Chiesi-Villa, C. Rizzoli. J. Chem. Soc., Dalton Trans. (1992) 108 t.

[15] G.M. Sheldick. Acta Crystallogr.. Sect. A 16 (1990) 467.

[16] G.M. Sheldrick, SHELXL93. University of Götingen. Germany. 1993. 